\title{
IMPLEMENTASI PELAYANAN TERPADU SATU PINTU NON-PERIZINAN DI UKUR DARI KEPUASAN MASYARAKAT DENGAN MENGGUNAKAN INDEKS KEPUASAN MASYARAKAT
}

\author{
Lia Melanie Ginting, Elisa Susanti ${ }^{2}$, Asep Sumaryana ${ }^{3}$ \\ Program Pasca Sarjana Kebijakan Publik \\ Fakultas Ilmu Sosial dan Ilmu Politik \\ Universitas Padjadjaran \\ liaginting12@gmail.com ${ }^{1}$, elisa.susanti@unpad.ac.id², asep.sumaryana@unpad.ac.id ${ }^{3}$
}

\begin{abstract}
ABSTRAK
Pelayanan Terpadu Satu Pintu sebagai salah satu wujud dari keinginan pemerintah untuk merubah kinerja pelayanan yang selama ini tidak memberikan layanan yang prima. Pelayanan Terpadu Satu Pintu di Unit Layanan Terpadu Kementerian Pendidikan Dan Kebudayaan merupakan pelayanan terpadu satu pintu yang memberikan layanan non-perizinan.
\end{abstract}

Penelitian ini menggunakan metode SMS (System Mapping Study) dan SLR (System Literatur Review) untuk mengetahui Kepuasan Masyarakat dengan menggunakan Indeks Kepuasan Masyarakat berdasarkan pada Peraturan Kemenpan R\&B No 25 Tahun 2004, tentang Indeks Kepuasan Masyarakat (IKM).

Kata Kunci: Implementasi, Kebijakan Publik, Pelayanan Terpadu Satu Pintu

\begin{abstract}
One Stop Integrated Service as a form of the government's desire to change the service performance that has not provided excellent service. One Stop Integrated Service in the Integrated Service Unit of the Ministry of Education and Culture is a one-stop integrated service that provides non-licensing services.

This research uses the method of SMS (System Mapping Study) and SLR (System Literature Review) to know Satisfaction of Society by using Satisfaction Index of Community based on Regulation of Kemenpan R \& B No. 25 Year 2004, about Satisfaction Index (IKM).
\end{abstract}

Key word: Implementation, Public Policy, One-Stop Service

\section{Pendahuluan}

One-Stop Service yaitu pelayanan yang dilakukan oleh suatu kantor, di mana masyarakat memerlukan pelayanan apa saja dapat dilakukan dengan menghubungi dan menerima layanan dari kantor tersebut yang berfungsi sebagai frontline yang juga sebagai backline. Berdasarkan Undang-Undang Nomor 25 Tahun 2009 tentang Pelayanan Publik, pasal 1 ayat (1), dijelaskan bahwa yang dimaksud dengan pelayanan publik adalah:

"Kegiatan atau rangkaian kegiatan dalam rangka pemenuhan kebutuhan pelayanan sesuai dengan peraturan perundaang-undangan bagi setiap warga ngara dan penduduk atas barang, jasa, dan/atau pelayanan administratif yang disediakan oleh penyelenggara pelayanan publik."
Yang dimaksud dengan Penyelenggara Pelayanan Publik adalah: Setiap institusi penyelenggara negara, korporasi, lembaga independen yang dibentuk berdasarkan undang-undang untuk kegiatan pelayanan publik, dan badan hukum lain yang di bentuk sematamata untuk kegiatan pelayanan publik. Tugas pelayanan itu merupakan tugas utama pemerintah dan tidak boleh dikomersilkan.

Dalam upaya meningkatkan kualitas pelayanan publik, pemerintah mulai tahun 1997 memperbaiki manajemen pelayanan publik dengan mengembangkan sistem pelayanan terpadu. Kemudian pada tahun 2006 melalui Departemen Dalam Negeri menerbitkan Permendagri Nomor 24 Tahun 2006 tentang Pedoman Penyelenggaraan Pelayanan Terpadu Satu Pintu yang menekankan kegiatan penyelenggaraan perizinan dan nonperizinan yang proses pengelolaannya mulai dari 


\section{Implementasi Pelayanan Terpadu Satu Pintu Non-Perizinan Di Ukur Dari Kepuasan Masyarakat Dengan Menggunakan Indeks Kepuasan Masyarakat (Lia Melanie Ginting, Asep Sumaryana, Elisa)}

tahap permohonan sampai ke tahap terbitnya dokumen dilaakukan dalam satu tempat”.

Dalam perkembangannya saat ini, dikenal ada dua pola penyelenggaraan pelayanan:

1. Pola Pelayanan Terpadu Satu Atap

Adalah pola pelayanan perijinan diselenggarakan dalam satu tempat yang meliputi berbagai jenis pelayanan tetapi tidak memiliki keterkaitan proses dan dilayani melalui beberapa loket (pintu) yang di dalamnya terdiri dari petugas unit kerja teknis pengelola perijinan. Kelemahan system ini adalah sulit dilakukan control oleh kepala pelayanan satu atap karena tidak memiliki kewenangan baik administrative maupun teknis. Sehingga jika timbul permasalahannya sulit untuk diatasi karena di luar tanggung jawabnya.

2. Pola Pelayanan Terpadu Satu Pintu

Jenis Pelayanan ini terdiri dari berbagai jenis pelayanan perijinan yang memiliki keterkaitan proses dan dilayani melalui satu pintu. Jenis pelayanan ini dapat dilakukan lebih cepat dan efisien karena dapat diproses secara paralel, karena baik secara administrative maupun teknis di selenggarakan dalam satu atap dan satu pintu. Untuk itu petugas front office melayani urusan administrative, sedangkan back-office melayani urusan-urusan teknis. Dengan demikian setiap penyimpangan dapat diantisipasi sebelumnya karena kepala unit pelayanan tetap memiliki kewenangan yang jelas dan pasti.

Salah satu konsep yang dikembangkan adalah model pelayanan yang mengintegrasikan berbagai jenis pelayanan pemerintah di satu lokasi. Model Pelayanan Publik seperti ini memiliki berbagai istilah seperti onestop government, integrated service delivery, seamlessgovernment, joined up governrrient, single access point, one stop shop, one-stop service (dalam Trochidis, 2008; Kubicek dan Hagen, 2001).

Adapun yang dimaksud dengan model onestop service atau pun one-stop government adalah pengintegrasian pelayanan public dari sudut pandang dan kepentingan masyarakat atau pelanggan (dalam Trochidis, 2008; Kubicek dan Hagen, 2001). Dengan model pelayanan public, semua urusan masyarakat atau pelanggan dapat dipenuhi di dalam satu kontak, baik secara tatap muka maupun menggunakan media lainnya seperti telepon atau internet. Model pelayanan seperti ini terutama dibutuhkan untuk memberikan jenis-jenis pelayanan administrative. Ciri-ciri pelayanan terpadu satu pintu adalah sebagai berikut:

1. Wewenang proses dan penandatanganan surat ijin berada di satu pihak yaitu instansi pelayanan. Khusus untuk pelayanan administrasi kependudukan, berdasarkan peraturan internasional, walaupun dilakukan di PTSP penandatanganannya tetap dilakukan oleh lembaga pencatatan sipil;
2. Koordinasi (dalam hal pelayanan dan proses perijinan) lebih mudah dan dilakukan oleh Kepala PTSP. Kepala PTSP juga berperan sebagai ketua Tim tinjauan lapangan (dan SKPD teknis lainnya sebagai anggota tim) untuk proses pemberian ijinijin tertentu;

3. Mekanisme dan prosedur akan lebih mudah disederhanakan karena keputusan berada di tangan kepala PTSP;

4. Pengawasan menjadi tanggung jawab bersama antara lembaga PTSP dan SKPD teknis;

5. SPM relative akan mudah dilakukan karena kewenangan mengkoordinir dan mengawasi pelaksanaan pelayanan berada di tangan satu pihak;

6. Lokasi pelayanan berada di satu tempat (terpusat) tetapi terdapat kemungkinan luas untuk melakukan inovasi dan terobosan pelayanan sesuai dengan kondisi daerah masing-masing, misalnya membuka cabang di berbagai lokasi, mobil keliling untuk menjemput berkas-berkas di berbagai kecamatan.

Lembaga pelayanan sebaiknya berbentuk kantor atau dinas yang bereselon II, sehingga tidak terjadi keseganan pimpinannya untuk mengkoordinasikan SKPD lainnya yang bereselon II. Masyarakat saat ini masih mendambakan pelayanan publik yang memuaskan. Namun harapan tersebut nampaknya masih jauh jadi kenyataan, karena kinerja pemerintah di nilai masih belum optimal. Orientasi pelayanan dari sebagian besar aparatur birokrasi pemerintah masih cenderung untuk melayani dirinya sendiri dalam arti pelayanan diarahkan untuk kepentingan birokrasi atau pejabat birokrasi bukannya pada masyarakat. Penyelenggaran pelayanan publik belum berbasis pada nilai-nilai efisiensi, dan transparansi. Hal ini berdampak pada pembangunan bidang ekonomi.

Menghadapi masalah ini, Tahun 1997 pemerintah memperbaiki manajemen pelayanan publik,khususnya aspek kelembagaan pelayanan perijinan dengan mengembangkan sistem pelayanan terpadu. Melalui Surat Edaran Nomor 503/125/PUOD tentang Pembentukan Pelayanan Terpadu Satu Atap, tahun 1998 ditetapkan Menteri Dalam Negeri Nomor 25 Tahun 1998 tentang Pelayanan Terpadu Satu Atap. Kemudian pada tahun 2006 kembali pemerintah melalui Departemen Dalam Negeri menerbitkan Permendagri Nomor 24 Tahun 2006 tentang Pedoman Penyelenggaraan Pelayanan Terpadu Satu Pintu sebagai bentuk implementasi dari Instruksi Presiden Nomor 3 Tahun 2006 tentang Paket Kebijakan Investasi.

Penelitian ini berjudul Implementasi Pelayanan Terpadu Satu Pintu Ditinjau Dari Kepuasan Masyarakat. Secara etimologis, kata implementasi berasal dari Bahasa Inggris "to implement", yang artinya pelaksanaan dan penerapan. Pengertian ini dipertegas 
oleh Hill and Hupe (2002:3-4) dan Pressman and Wildavsky (1984:xxi), bahwa:

"Implementation, to us, means just what Webster and Roger say it does: to carry out, accomplish, fulfil, produce, complete. But what is it being implemented? A policy, naturally. There must be something out there prior to implementation; otherwise there would be nothing to move toward in the process of implementation. A verb like 'implement' must have an object like 'policy'. But policies normally contain both goals and the means for achieving them. How, then, do we distinguish between a policy and its implementation?”

Pemikiran tersebut menunjukkan bahwa pada dasarnya implementasi adalah untuk melaksanakan kebijakan yang harus mempunyai objek seperti kebijakan yang dapat menimbulkan sesuatu dampak tercapainya atau tidaknya sesuatu kebijakan dengan menggunakan sarana-sarana untuk melaksanakan kebijakan tersebut.

Penyelenggaraan pelayanan terpadu satu pintu di Kementerian Pendidikan Dan Kebudayaan dimulai 3 tahun yang lalu yakni pada tahun 2014. Jadi, semua layanan yang di miliki unit teknis dijadikan satu di Pelayanan Terpadu Satu Pintu.

Pelayanan Terpadu Satu Pintu Kementerian Pendidikan Dan Kebudayaan berada di bawah Eselon II (dua) Setjen yakni di Biro Komunikasi Dan Layanan Masyarakat (BKLM), tepatnya di Bagian Layanan Terpadu dan di beri nama Unit Layanan Terpadu (ULT) berdasarkan Permendikbud Nomor 11 Tahun 2018 tentang Organisasi dan Tata Kerja Kementerian Pendidikan Dan Kebudayaan.

Pada Bulan September 2015 Unit Layanan Terpadu mulai melakukan survey pengunjung dalam bentuk kuesioner. Pertanyaan yang ditanyakan di dalam kuesioner tersebut adalah:

1. Persyaratan Layanan;

2. Waktu Pelayanan;

3. Biaya/tarif;

4. Produk Spesifikasi Jenis Layanan;

5. Kompetensi Pelaksana;

6. Perilaku Pelaksana;

7. Maklumat Pelayanan;

8. Penanganan Pengaduan, Saran dan Masukkan.

Delapan (8) pertanyaan tersebut merupakan indeks kepuasan masyarakat (IKM) yang diadopsi dari indeks kepuasaan masyarakat (IKM) berdasarkan peraturan Kemenpan R\&B No. 25 Tahun 2004, tentang Indeks Kepuasan Masyarakat (IKM).

Masyarakat saat ini masih mendambakan pelayanan publik yang memuaskan. Namun harapan tersebut nampaknya masih jauh jadi kenyataan, karena kinerja pemerintah di nilai masih belum optimal. Orientasi pelayanan dari sebagian besar aparatur birokrasi pemerintah masih cenderung untuk melayani dirinya sendiri dalam arti pelayanan diarahkan untuk kepentingan birokrasi atau pejabat birokrasi bukannya pada masyarakat.

Permendagri Nomor 24 Tahun 2006 menjelaskan bahwa yang dimaksudkan dengan Penyelenggaraan Pelayanan Terpadu Satu Pintu adalah: "Kegiatan penyelenggaraan perizinan dan non perizinan yang proses pengelolaannya mulai dari tahap permohonan sampai ke tahap terbitnya dokumen dilakukan dalam satu tempat.”

Tujuan Pelayanan Terpadu Satu Pintu ini untuk meningkatkan kualitas pelayanan publik dan memberikan akses yang lebih luas kepada masyarakat untuk memperoleh pelayanan publik. Dengan disahkannya Undang-undang Nomor 25 Tahun 2009 tentang Pelayanan Publik semakin memperkuat komitmen pemerintah untuk meningkatkan kualitas pelayanan publik.

Ratminto \& Winarsih (2006) mengartikan pelayanan sebagai "suatu aktivitas atau serangkaian aktivitas yang bersifat tidak kasat mata (tidak dapat diraba) yang terjadi sebagai akibat adanya interaksi antara konsumen dengan karyawan atau hal-hal lain yang disediakan.” Lebih jauh Ratminto \& Winarsih menjelaskan bahwa pelayanan adalah produk-produk yang tidak kasat mata (tidak dapat diraba) yang melibatkan usaha-usaha manusia dan menggunakan peralatan. Fitzsimmons dan Fitzsimmons (2004), menjelaskan Pelayanan sebagai berikut:

"Proses yang diciptakan dan digunakan secara atau hampir simultan.”

Pelayanan menurut Fitzsimmons dan Fitzsimmons bersifat tidak nyata (intangible) dan tidak tahan lama, karena pelanggan tidak dapat menyimpan jasa tersebut setelah dihasilkan tapi efeknya dapat disimpan terus oleh pelanggan.

Ratminto \& Winarsih (2006) menginventarisasi terdapat tujuh karakteristik dari pelayanan:

1. Konsumen memiliki kenangan: pengalaman atau memori tersebut tidak dapat dijual atau diberikan kepada orang lain;

2. Tujuan penyelenggaraan pelayanan adalah keunikan: setiap konsumen dan setiap kontak adalah spesial;

3. Suatu pelayanan terjadi saat tertentu: ini tidak dapat disimpan di gudang atau dikirimkan contohcontohnya;

4. Konsumen adalah 'rekanan yang terlibat dalam proses produksi';

5. Konsumen melakukan kontrol kualitas dengan cara membandingkan harapannya dengan pengalamannya;

6. Jika terjadi kesalahan, satu-satunya cara yang bisa dilakukan untuk memperbaiki adalah meminta maaf;

7. Moral karyawan berperan sangat menentukan. 


\section{Implementasi Pelayanan Terpadu Satu Pintu Non-Perizinan Di Ukur Dari Kepuasan Masyarakat Dengan Menggunakan Indeks Kepuasan Masyarakat (Lia Melanie Ginting, Asep Sumaryana, Elisa)}

Berdasarkan karakteristik pelayanan tersebut jelas bahwa pelayanan berkaitan dengan aktivitas-aktivitas yang bersifat tidak nyata yang diberikan oleh suatu organisasi untuk memenuhi kebutuhan pengguna pelayanan itu sendiri dan pengguna pelayanan memiliki peran yang cukup besar untuk menentukan apakah pelayanan tersebut berkualitas atau tidak.

Pelayanan Umum menurut Keputusan Menteri Pendayagunaan Aparatur Negara Nomor 63/KEP/M.PAN/7/2003 tentang Pedoman Penyelenggaraan Pelayanan sebagai berikut:

"Segala bentuk pelayanan yang dilaksanakan oleh instansi pemerintah di Pusat, di Daerah dan di lingkungan Badan Usaha Milik Negara atau Badan Usaha Milik Daerah dalam bentuk barang dan atau jasa, baik dalam rangka upaya pemenuhan kebutuhan masyarakat maupun dalam rangka pelaksanaan ketentuan peraturan perundang-undangan."

Kualitas pelayanan merupakan komponen penting yang harus diperhatikan dalam pelayanan publik. Secara konseptual istilah kualitas menurut Gaspersz (2005) memiliki banyak pengertian. Menurutnya secara konvensional, kualitas diartikan sebagai gambaran karakteristik langsung dari suatu produk seperti "performasi (performance), keandalan (reliability), mudah dalam penggunaan (ease of use), estetika (esthetics). Sedangkan dalam pengertian secara strategik, kualitas diartikan sebagai segala sesuatu yang mampu memenuhi keinginan atau kebutuhan pelanggan (meeting the needs of customers).

Wyckoff (1978:177), mengatakan bahwa:

"Quality is the degree of excellence intended, and the controll of variability in achieving that excellence, in meeting the customer's requirements."

(kualitas adalah tingkat keprimaan yang diinginkan dan pengawasan terhadap pelbagai variabel dalam pemenuhan apa yang diinginkan pelanggan).

Perumusan kualitas sangat penting dalam hubungannya dengan penyusunan rancangan kualitas (quality design) yang diinginkan, kesesuaian kualitas atau minimalisasi kesenjangan dari yang dirancang (confirmity quality); dan kesesuaiannya dengan rancangan kualitas sehingga layanan sesuai dengan yang diinginkan konsumen.

Pelayanan publik yang berkualitas menyangkut kapabilitas organisasi dalam melayani masyarakat, karena itu perlu dikelola dengan baik melalui manajemen pelayanan yang excellent. Manajemen pelayanan yang dikemukakan oleh Albrecht (1986) merupakan pendekatan totalitas organisasi untuk meningkatkan mutu pelayanan seperti yang diharapkan para konsumen. Menurut Loverlock (1992) manajemen pelayanan memiliki empat fungsi utama yaitu: a) Memahami persepsi masyarakat yang senantiasa berubah tentang nilai dan kualitas jasa atau produk;

b) Memahami kemampuan sumber daya dalam menyediakan pelayanan;

c) Memahami arah pengembangan lembaga pelayanan agar nilai dan kualitas yang diinginkan masyarakat terwujud;

d) Memahami fungsi lembaga pelayanan agar nilai dan kualitas jasa/produk terwujud dan kebutuhan setiap stakeholder tercapai.

Berdasarkan pendapat-pendapat tersebut terlihat bahwa manajemen atau pengelolaan pelayanan diarahkan pada peningkatan kualitas pelayanan yang dalam hal ini sesuai dengan tuntutan dan kebutuhan pengguna (pelanggan atau masyarakat) dengan memperbaiki berbagai aspek internal dalam organisasi pelayanan itu sendiri.

Menurut McKevitt (1998) karena pelayanan publik merupakan aspek penting dalam melindungi dan meningkatkan kesejahteraan masyarakat maka organisasi pelayanan publik harus dikelola dengan sebaik-baiknya agar dapat memberikan pelayanan yang baik. Manajemen pelayanan publik yang efektif dan efisien menurutnya meliputi tiga fungsi utama yaitu:

1. Memberikan pelayanan kepada pelanggan,

2. Mengembangkan kapasitas pelayanan dan peningkatan pembiayaan,

3. Melaksanakan proses pelayanan publik yang meliputi pengawasan, pengorganisasiaan dan hubungan antar manusia.

Struktur pemerintah yang bersifat hirarkis dan fungsional sering menjadi penghambat masyarakat dan kalangan dunia usaha untuk berhubungan dengan berbagai instansi pemerintah dalam rangka memenuhi kebutuhannya. Menurut Trochidis (2008) perlu dikembangkan model kelembagaan pelayanan publik yang dapat memudahkan masyarakat dan kalangan dunia usaha untuk berurusan dengan pemerintah. Salah satu konsep yang dikembangkan adalah model pelayanan yang mengintegrasikan berbagai jenis pelayanan pemerintah di satu lokasi yang di sebut onestop service atau one-stop government. Menurut Trochidis (2008) sistem pelayanan publik terintegrasi menjanjikan pemberian pelayanan yang mulus dari berbagai organisasi pemerintah, menciptakan efisiensi dan pengalaman pelayanan yang lebih baik bagi penyedia layanan serta pengguna layanan itu sendiri. Yang dimaksud dengan model one-stop service atau pun one-stop government adalah pengintegrasian pelayanan publik dari sudut pandang dan kepentingan masyarakat atau pelanggan (dalam Trochidis, 2008; Kubicek dan Hagen, 2001).

Negara-negara maju untuk menjawab tuntutan tersebut melakukan berbagai reformasi dalam pelayanan publiknya seperti mencari dan mengembangkan modelmodel atau bentuk-bentuk baru sistem pelayanan publik, 
khususnya pelayanan publik yang bersifat administratif. Pelayanan administratif juga merupakan kewajiban dan untuk kepentingan pemerintah sendiri dikembangkan ke arah model-model yang memberikan kemudahan kepada masyarakat untuk memperoleh pelayanan tersebut. Begitu pula halnya di Indonesia, sejak tahun 1990an telah timbul pemikiran untuk mereformasi manajemen pelayanan publik.

Salah satu bentuk reformasi pelayanan publik khususnya untuk pelayanan administratif, pemerintah mengembangkan model-model kelembagaan baru seperti model pelayanan terpadu satu pintu atau PTSP. Beberapa kebijakan yang melandasi pembentukan model pelayanan terpadu satu pintu adalah sebagai berikut:

- Surat Edaran Menteri Dalam Negeri Nomor 503/125/PUOD Tahun 1997 tentang Pembentukan Pelayanan Terpadu Satu Atap.

- Instruksi Menteri Dalam Negeri Nomor 25 Tahun 1998 tentang Pelayanan Terpadu Satu Atap.

- Keputusan Menteri Pendayagunaan Aparatur Negara Nomor 63/2003 tentang Pedoman Umum Pelayanan Publik.

- Permendagri Nomor 24 Tahun 2006 tentang Pedoman Penyelenggaraan Pelayanan Terpadu Satu Pintu.

- Instruksi Presiden Nomor 3 Tahun 2006 tentang Paket Kebijakan Investasi.

- Peraturan Menteri Dalam Negeri Nomor 20 Tahun 2008 tentang Pedoman Organisasi dan Tata Kerja Unit Pelayanan Perijinan Terpadu di Daerah.

- $\quad$ Peraturan Presiden Nomor 27 Tahun 2009 tentang Pelayanan Terpadu Satu Pintu di Bidang Penanaman Modal

- $\quad$ Peraturan Presiden Nomor 97 Tahun 2014 tentang Penyelenggaraan Pelayanan Terpadu Satu Pintu.

Dengan adanya kebijakan-kebijakan tersebut terlihat adanya upaya pemerintah untuk melakukan reformasi pelayanan publik khususnya yang berkaitan dengan jenis pelayanan administratif. Berdasarkan rumusan tersebut maka kebijakan pelayanan terpadu satu pintu bertujuan untuk meningkatkan kualitas pelayanan publik baik untuk pelayanan perijinan maupun nonperijinan dengan melakukan penyederhanaan penyelenggaraan pelayanan yang dipusatkan di satu tempat. Penyederhanaan ini dengan tujuan untuk makin meningkatkan kualitas pelayanan publik dalam bentuk penyelenggaraan pelayanan yang cepat, murah, mudah, transparan, pasti dan terjangkau. Bentuk dasar hukum ini yang melandasi pembentukan PTSP mencerminkan pula sikap, tingkat kesadaran dan komitmen lembaga legislatif dan eksekutif terhadap peningkatan kualitas pelayanan publik.
Tujuan pembentukan pelayanan terpadu satu pintu pada dasarnya adalah untuk menyederhanakan penyelenggaraan pelayanan baik pelayanan yang bersifat perijinan maupun nonperijinan.

\section{Metode Penelitian}

Pada artikel ini peneliti menggunakan metode SMS (Sistem Mapping Studi) dan SLR (Sistem Literatur Riview), yaitu peneliti melakukan pemetaan/mapping jurnal yang terkait dengan makalah ini yakni tentang Implementasi Pelayanan Terpadu Satu Pintu atau OneStop Service (OSS) non-perizinan terhadap kepuasan masyarakat yang terkait dengan dunia pendidikan, tempat penelitiannya di Unit Layanan Terpadu (ULT) Kementerian Pendidikan Dan Kebudayaan. Pemetaan /Mapping dan Literatur Rieview dari jurnal terakreditasi Dikti yakni Ipi dan Science Direct.

Result:

Di Ipi (id.portalgaruda.org), penulis menemukan 49 artikel dengan kata kunci pelayanan terpadu satu pintu, yang penulis ambil hanya 14 Jurnal dari Ipi (id.portalgaruda.org) yang terkait dengan penelitian penulis dan juga penulis mengambil 1 (satu) jurnal dari Scince Direct, antara lain sebagai berikut:

1. Implementasi One Stop Service (OSS) Pada Badan Pelayanan Perizinan Terpadu (BP2T) Kota Manado, yang diteliti oleh Inri Monica Priscila Meray.

Manado sebagai ibu kota Sulawesi Utara berkembang pesat, oleh karena itu memerlukan kerjasama dari banyak pihak, tidak hanya dari pemerintah tetapi juga dari berbagai elemen masyarakat untuk mengembangkan Manado menjadi lebih baik. Dalam prakteknya masih banyak masalah yang perlu diatasi, misalnya, dalam memperoleh izin masih ada masalah pada sistem birokrasi di mana lisensi masih berbelit-belit oleh beberapa instansi.

Pemerintah Kota Manado dalam hal ini sebagai pembuat kebijakan memiliki komitmen yang jelas kepada masyarakat yang juga termasuk dalam layanan di mana telah dinyatakan dalam Peraturan Daerah Kota Manado Nomor 05 Tahun 2008 Tentang Organisasi dan Dinas Pelayanan Perizinan Terpadu dan Peraturan Utama Manado Nomor 40 Tahun 2008 Tentang Rincian Tugas dan Fungsi Badan Pelayanan Perizinan Terpadu Manado.

Namun, dalam penelitian ini peneliti menemukan kebijakan Pemerintah Kota Manado dalam hal memperoleh izin sebagai one stop service -'One Roof One Door'- belum dilaksanakan dengan baik yang masih ada kendala, antara lain, sumber daya manusia yang profesional dan kebijakan dalam penerbitannya. perizinan (SOP), dengan memperbaiki masalah ini maka semoga masa depan 


\section{Implementasi Pelayanan Terpadu Satu Pintu Non-Perizinan Di Ukur Dari Kepuasan Masyarakat Dengan Menggunakan Indeks Kepuasan Masyarakat (Lia Melanie Ginting, Asep Sumaryana, Elisa)}

layanan publik - dalam hal ini mendapatkan izin oleh pengusaha dan masyarakat - akan menjadi lebih baik dan pada akhirnya akan mengarah pada kemakmuran Pemerintah Kota dan Masyarakat Manado.

2. Implementasi Pelayanan Perizinan Terpadu Satu Pintu Oleh Yuli Tirtariandi El Anshori, Enceng dan Anto Hidayat;

Implementasi Pelayanan Perizinan Terpadu Satu Pintu. Tujuan penelitian adalah menemukan gambaran tentang implementasi PTSP khususnya di Kabupaten Bangka. Metode yang digunakan adalah pendekatan deskriptif kualitatif. Data primer diperoleh dari wawancara dan observasi. sedangkan data sekunder diperoleh dari studi dokumentasi. Analisis data menggunakan metode triangulasi. Hasil penelitian menunjukkan bahwa komitmen pelaksanaan PTSP di Kabupaten Bangka dari kepala daerah sudah baik, tetapi kendala ditemukan dalam hal fungsi koordinasi antara lembaga pelaksana PTSP dengan SKPD teknis karena perbedaan eselonisasi. Imbas tarik menarik kepentingan antara kedua lembaga tersebut dalam pelayanan publik perizinan dapat berdampak pada rendahnya kepercayaan pelaku usaha terhadap birokrat pemberi pelayanan publik.

3. Pelayanan Terpadu Satu Pintu Sebagai Upaya Peningkatan Pelayanan Perizinan (Studi Pada Kantor Pelayanan Perizinan Kota Kediri) Oleh Achmad Nur Haida, Choirul Saleh, Romula Adiono;

Pelayanan Terpadu Satu Pintu Sebagai Upaya Peningkatan Pelayanan Perizinan. Penelitian ini dilakukan atas dasar keluhan masyarakat umun dan kalangan dunia usaha mengenai proses pelayanan perizinan oleh pemerintah daerah yang terkesan berbelit-belit, tidak transparan dan perlu biaya ekstra. Masyarakat sering bolak-balik dari satu kantor ke kantor lainnya hanya untuk mengurus suatu perizinan. Ketidak jelasan prosedur, biaya dan waktu pemrosesan suatu izin yang tidak pasti selesainya yang menyebabkan biaya yang dikeluarkan menjadi lebih tinggi. Melihat permasalahan tersebut perlu adanya upaya dari pemerintah daerah untuk meningkatkan pelayanan publik terutama dalam hal pelayanan perizinan. Penelitian ini bertujuan untuk mendiskripsikan upaya, pelaksanaan dan faktor pendukung dan penghambat dari pelaksanaan Pelayanan Terpadu Satu Pintu di Kantor Pelayanan Perizinan Kota Kediri. Penelitian menggunakan metode deskriptif dengan pendekatan kualitatif. Fokus permasalahannya adalah (1) Upaya KPP dalam meningkatkan pelayanan perizinan (2) Pelaksanaan pelayanan perizinan di KPP (3) Faktor pendukung dan penghambat dalam pelaksanaan perizinan di KPP. Hasil dari penelitian ini adalah upaya yang dilakukan KPP untuk meningkatkan kualitas pelayanan perizinan dengan PTSP sudah cukup baik, meskipun ada beberapa faktor penghambat dari pelaksanaan, tetapi kendala tersebut masih bisa diminimalisir oleh pegawai KPP.

4. The Implementation Of Integrated One-Stop Service at Licensing Service Agency In Order To Improve Licensing Service To Society (Case Study On Business License Service At Investment And Integrated Licensing Service Agency (IILSA) Of Pasuruan City) oleh Priyani Dini Pramita, Siti Rochmah, Ratih Nur Pratiwi;

Studi ini membahas tentang implementasi layanan perizinan terpadu satu pintu yang terkait dengan layanan SIUP, yang dilakukan oleh Badan Pelayanan Perizinan dan Izin Terpadu (IILSA) di Kota Pasuruan. Secara umum ada masalah terkait Lisensi untuk kegiatan bisnis, yaitu: prosedur yang rumit, biaya tinggi dan ketidakpastian hukum. Untuk mengatasi masalah ini pemerintah mengeluarkan Permendagri nomor 24 tahun 2006 tentang Pedoman Pelaksanaan Pelayanan Terpadu Satu Pintu. Fokus dari penelitian ini membahas implementasi layanan terpadu satu atap, berdasarkan pada aturan yang terkait dengan melihat beberapa elemen berikut: (1) aktor pelaksana (2) komunikasi (3) sumber daya (4) struktur birokrasi (5) kelompok sasaran. Penelitian ini menggunakan metode deskriptif dengan pendekatan penelitian kualitatif. Aktivitas analisis data dalam penelitian ini terdiri dari reduksi data, display dan verifikasi data. Hasil penelitian ini dapat dikatakan bahwa implementasi yang dilakukan oleh IILSA Kota Pasuruan sudah baik walaupun ada beberapa hal yang perlu ditingkatkan terkait koneksi internet yang masih menjadi kendala dalam pelaksanaan operasional dalam penyampaiannya. layanan untuk SIUP dan juga kurangnya sarana dan prasarana yang tersedia.

5. Penyelenggaraan Pelayanan Terpadu Satu Pintu Pada Dinas Perijinan Kota Denpasar Oleh I Putu Agus Indra Febriyana, Cok Istri Anom Pemayun;

Penyederhanaan prosedur perijinan melalui pembentukan Dinas Perijinan merupakan salah satu upaya yang diharapkan bisa mengakomodasi kebutuhan masyarakat sebagai lembaga yang benar-benar One Stop Service, dimana berbagai jenis perijinan yang saat ini masih ada tersebar di sekian banyak SKPD, dalam 105 jenis perijinan, semuanya diurus dalam satu pintu, yaitu di Dinas Perijinan, kebijakan Pemerintah Kota Denpasar dalam penyederhanaan perijinan dengan Sistem Paralel tersebut menimbulkan permasalahan yaitu bagaimanakah penyelenggaraan pelayanan terpadu 
satu pintu dalam upaya peningkatan pelayanan pada masyarakat di Dinas Perijinan Kota Denpasar, dan Apakah yang menjadi tolok ukur agar tercapainya penyelenggaraan pelayanan terpadu satu pintu yang baik di Dinas Perijinan Kota Denpasar. Metode ini merupakan jenis penelitian empiris. Dapat disimpulkan dari faktor-faktor upaya peningkatan pelayanan dengan melalui dua prosedur Front Office dan Back Office agar mudah dan cepat mengurus ijin. Dan masyarakat juga dalam mengajukan permohonan ijin harus sesuai persyaratan permohonan yang dimiliki Dinas Perijinan Kota Denpasar agar tidak adanya hambatan dan kendala dalam Penyelenggaraan Pelayanan Terpadu Satu Pintu dan bisa berjalan dengan baik.

6. Kinerja Organisasi Pelayanan Publik Pada Kantor Pelayanan Terpadu Satu Pintu Kabupaten Sintang Oleh Sri Hartati, Netti Herawati, Endang Indri Listiani;

Kinerja pelayanan publik yang diselenggarakan oleh Kantor Pelayanan Terpadu Satu Pintu Kabupaten Sintang belum mencerminkan pelayanan prima. Hal ini terlihat dari aspek kualitas layanan, dan reponsivitas yang masih belum terwujud. Rendahnya kualitas meliputi aspek waktu pelayanan masih membutuhkan waktu yang lama dan tidak sesuai dengan SOP, prosedur pelayanan masih kurang dimengerti oleh masyarakat dan perlakuan petugas pemberi layanan kurang menunjukkan kemampuan. keterampilan, dan etika yang memadai. Adanya keluhan dari masyarakat terkait dengan proses pelayanan kurang ditanggapi dengan cepat oleh penyelenggara pelayanan sehingga menimbulkan ketidakpuasan masyarakat. Belum maksimalnya kinerja pelayanan publik yang diselenggarakan oleh Kantor Pelayanan Terpadu Satu Pintu di Kabupaten Sintang dalam bidang perizinan meliputi faktor kualitas personil, ketatalaksanaan dan sumber daya keuangan dan peralatan yang msih kurang memadai. Kondisi pelayanan demikian menunjukkan bahwa pelayaan yang diberikan belum memenuhi prinsip standarisasi pelayanan yang diatur dalam Kepmenpan Nomor 63 Tahun 2003.

7. Pengaruh iklim organisasi terhadap kinerja karyawan pada bagian pelayanan terpadu satu pintu di kantor kota administrasi jakarta pusat, Oleh Hastuti, Lady Anugrah:

Penelitian ini bertujuan untuk menguji pengaruh sub variabel iklim organisasi terhadap kinerja karyawan pada kantor Kota Administrasi Jakarta Pusat bagian Pelayanan Terpadu Satu Pintu (PTSP). Penelitian ini menggunakan data primer dan data sekunder. Data Sekunder didapatkan dari beberapa sumber seperti jurnal dan buku. Data primer didapatkan melalui penyebaran kuesionair dengan menggunakan teknik sensus yaitu jumlah populasi sama dengan jumlah responden. Uji validitas dan reliabilitas digunakan untuk menguji Instrumen penelitian. Hasil penelitian menunjukkan bahwa pengujian dilakukan berdasarkan analisa parsial, dan diketahui yang memiliki pengaruh adalah instrumen kondisi fisik lingkungan kerja terhadap kinerja karyawan. Sementara itu, pengujian secara bersama sama atau simultan dilakukan dan ditemukan hasilnya bahwa dimensi divariabel iklim organisasi secara bersama sama berpengaruh terhadap kinerja karyawan.

8. Studi Evaluasi Proses Pelayanan Prima Perijinan Terpadu Satu Pintu di BPPT Kota Semarang, Oleh Putri Widayanti:

Dalam melakukan pelayanan publik kepada masyarakat, hal yang paling penting itu, seharusnya yang diutamakan di masyarakat adalah kepuasan dalam mendapatkan layanan. Penyediaan layanan publik sesuai dengan standar layanan publik adalah proses pelayanan prima kepada masyarakat. Layanan terbaik adalah yang terbaik layanan diberikan dengan penekanan pada kesederhanaan, kecepatan, ketepatan waktu dan kepatuhan standar yang berlaku untuk menciptakan kepuasan kepada publik. Masalah-masalah dibahas dalam penelitian ini termasuk upaya yang dilakukan dalam mencapai pelayanan prima dan faktor-faktor membatasi apa pun yang dihadapi dalam mencapai penghargaan layanan prima kepada masyarakat pada layanan badan perizinan terpadu (BPPT) Kota Semarang. Penelitian ini menggunakan metode penelitian kualitatif evaluasi. Fokus dari studi meliputi: (1) upaya dalam mewujudkan BPPT pelayanan prima kepada masyarakat, (2) faktor penghambat yang dihadapi dalam mencapai BPPT memberikan layanan yang sangat baik kepada masyarakat. Berdasarkan hasil evaluasi kualitatif dari penelitian yang diperoleh hasil dan diskusi yang menunjukkan bahwa upaya dalam hal yang sangat baik layanan di BPPT Kota Semarang masih ada beberapa kendala. Berbagai factor membatasi yang perlu diperbaiki, yaitu keberadaan tim teknis masih dalam layanan dari departemen lain yang bersangkutan, ketidakpastian waktu penyelesaian perizinan, infrastruktur dan fasilitas, keberadaan calo yang membuat biaya lisensi menjadi dua kali lipat, pemrosesan izin file harus masih keluar untuk departemen terkait serta file yang tidak lengkap dari pelamar. Proses pelayanan prima masih jauh dari apa yang diharapkan oleh masyarakat. BPPT Kota Semarang seharusnya lebih ketat dalam melakukan superintendence menuju calo dan mendapatkan calo penuh dalam penerbitan izin sehingga memberi layanan menjadi lebih efektif dan efisien. 


\section{Implementasi Pelayanan Terpadu Satu Pintu Non-Perizinan Di Ukur Dari Kepuasan Masyarakat Dengan Menggunakan Indeks Kepuasan Masyarakat (Lia Melanie Ginting, Asep Sumaryana, Elisa)}

9. Pengaruh kompetensi dan motivasi terhadap kinerja pegawai negeri sipil di lingkungan badan penanaman modal dan pelayanan terpadu satu pintu (bpmptsp) provinsi kalimantan Barat, Oleh Budi Setiawan:

Penelitian ini bertujuan untuk memperoleh gambaran tentang kompetensi, motivasi, dan kinerja Pegawai Negeri Sipil di BPMPTSP. Disamping itu penelitian ini juga bertujuan untuk mengetahui pengaruh kompetensi dan motivasi terhadap kinerja Pegawai Negeri Sipil di BPMPTSP Provinsi Kalimantan Barat. Jenis penelitian yang dilaksanakan adalah deskriptif dan asosiatif. Sampel dalam penelitian ini adalah seluruh Pegawai Negeri Sipil BPMPTSP Provinsi Kalimantan Barat yang berjumlah 55 orang. Pengumpulan data dilakukan dengan menggunakan kuesioner yang telah diuji validitas dan reliabilitasnya. Data dianalisis menggunakan analisis jalur (path analysis). Hasil analisis deskriptif menunjukkan bahwa kompetensi, motivasi, dan kinerja Pegawai Negeri Sipil BPMPTSP Provinsi Kalimantan Barat tergolong baik sekali. Hasil pengujian statistik menunjukkan bahwa kompetensi berpengaruh signifikan terhadap kinerja sebesar 0,369, dan motivasi berpengaruh signifikan terhadap kinerja sebesar 0,195. Pengaruh bersama-sama antara kompetensi dan motivasi terhadap disiplin kerja sebesar 63,80\%, sedangkan sisanya sebesar $36,20 \%$ ditentukan oleh variabel lain yang tidak teridentifikasi dalam penelitian ini.

10. Efektivitas organisasi kantor pelayanan perizinan terpadu satu pintu di kabupaten kayong utara, Oleh Utin Ernalita:

Tujuan penelitian ini adalah mendeskripsikan dan menganalisis efektivitas jangka pendek Kantor Pelayanan Perizinan Terpadu Satu Pintu (KPPTSP) dalam pelayanan bidang perizinan di Kabupaten Kayong Utara, serta mengetahui dan menganalisis kendala yang menghambat efektivitas jangka pendek KPPTSP dalam pelayanan bidang perizinan di Kabupaten Kayong Utara. Â Hasil penelitian menunjukkan bahwa pembentukan KPPTSP Kabupaten Kayong Utara sudah mampu memenuhi harapan pemerintah dan masyarakat Kayong Utara, untuk mewujudkan pelayanan perizinan maksimal secara transparan dan tepat waktu, akan tetapi masih terdapat beberapa permasalahan menyangkut efektivitas jangka pendek KPPTSP. Ditinjau dari produksi (production), pelayanan perizinan yang diselenggarakan oleh KPPTSP Kabupaten Kayong Utara dilihat dari jangkauan perizinan investasi yang dilayani oleh KPPTSP masih dalam lingkup Kabupaten Kayong Utara, tetapi untuk investasi dari luar daerah belum pernah ditangani. Ditinjau dari efisiensi (efficiency), masih terdapat pelayanan yang belum sesuai dengan standar waktu yang ditetapkan dalam SOP pelayanan KPPTSP, yang diakibatkan minimnya dukungan jumlah pegawai dan fasilitas kerja. Ditinjau dari aspek kepuasan (satisfaction), pelayanan perizinan belum sepenuhnya dapat memberikan kepuasan kepada masyarakat, karena belum tersedia informasi pelayanan yang mudah diakses, ruang pelayanan yang belum memadai serta belum ada jaminan kepastian waktu. Adapun kendala yang menyebabkan pelayanan perizinan yang diberikan belum maksimal adalah minimnya dukungan sumber daya manusia KPPTSP baik dari segi jumlah maupun kompetensi. Dukungan pendanaan bagi KPPTSP yang belum sesuai dengan kebutuhan. Dukungan terhadap sarana dan prasarana KPPTSP belum memenuhi standar pelayanan terpadu satu pintu. Koordinasi antar unit kerja yang belum berjalan dengan maksimal.

11. Analisis faktor-faktor yang mempengaruhi kualitas pelayanan terpadu satu pintu dalam rangka mewujudkan pemerintahan yang baik di kabupaten takalar, Oleh Dahyar Daraba:

Penelitian ini bertujuan untuk menganalisis pengaruh struktur organisasi, kemampuan aparat, sarana prasarana dan sistem pelayanan terhadap kualitas pelayanan terpadu satu pintu di Kabupaten Takalar. Populasi Penelitian ini adalah pegawai pada Kantor Pelayanan Terpadu Satu Pintu (KPTSP) di Kabupaten Takalar yang berjumlah 34 orang. Berdasarkan pertimbangan bahwa sebaran populasi mudah dijangkau dan jumlah yang tidak terlalu banyak, maka jenis penelitian ini termasuk penelitian populasi. Jenis data yang dikumpulkan berupa data yang bersifat kualitatif dan kuantitatif. Teknik pengumpulan data yang digunakan adalah kuesioner dengan menggunakan skala Likert. Selain itu, dilakukan pula telaah dokumen, yaitu pengumpulan data-data melalui buku-buku, laporan, jurnal atau tulisan ilmiah yang mempunyai hubungan dengan masalah yang diteliti. Analisis data digunakan regresi berganda. Hasil penelitian menjelaskan bahwa struktur organisasi, kemampuan aparat sarana/prasarana dan sistem pelayanan secara bersama berpengaruh signifikan terhadap kualitas pelayanan di Kantor PTSP Kabupaten Takalar. Sedangkan secara parsial berdasarkan uji-t juga menjelaskan keempat faktor tersebut memberikan pengaruh signifikan terhadap kualitas pelayanan. Faktor kemampuan yang dominan berpengaruh terhadap kualitas pelayanan.

12. Analisis Indeks Kepuasan Masyarakat Pada Pelayanan Perijinan Di Badan Penanaman Modal Dan Pelayanan Perizinan Terpadu Satu Pintu (BPMPPTSP) Kabupaten Semarang, Oleh Nopiyanti, Hadi Warsono, Rihandoyo: 
Pengukuran Indeks Kepuasan Masyarakat mengacu pada KEMENPAN No. 25 tahun 2004 tentang Indeks Kepuasan Masyarakat (IKM). Tujuan Pengukuran Indeks Kepuasan Masyarakat adalah untuk menentukan perkembangan kinerja unit dalam pelayanan instansi pemerintah itu dilaksanakan oleh instansi terkait secara berkala dan dapat digunakan sebagai bahan untuk mereka sendiri kebijakan untuk lebih meningkatkan kualitas layanan publik. Sedangkan tujuan penelitian pengukuran IKM: bagaimana tingkat kepuasan pelanggan, sadar akan unsur-unsur yang harus diperhatikan ditingkatkan dan bagaimana meningkatkan kepuasan masyarakat. Pengukuran Kepuasan Masyarakat. Indikator oleh KEMENPAN No. 25 tahun 2004 adalah Prosedur, Persyaratan Layanan, Kejelasan Petugas Layanan, Petugas Disiplin, Petugas Layanan Tanggung Jawab, Kemampuan Petugas Layanan, Kecepatan Layanan, Keadilan Mendapatkan Perawatan, Courtesy dan Petugas perhotelan, Keadilan Care Biaya, Biaya Jasa Jaminan, Jadwal Layanan Jaminan, Keselamatan, Lingkungan dan Keamanan Jasa. Berdasarkan indikator pengukuran kepuasan publik dalam Investasi dan Layanan Agency One Stop (BPMPPTSP) di Kabupaten Semarang, Penulis merekomendasikan sebagai berikut: (1) Fasilitas Perbaikan dan layanan dukungan Infrastruktur, dan (2) Peningkatan elemen kenyamanan untuk izin pengguna untuk menciptakan lingkungan yang kondusif bagi pengguna.

13. Peranan Pegawai Negeri Sipil Dalam Penyelenggaraan Pelayanan Terpadu Satu Pintu, Oleh Putu Ayu Mitha Ananda Putri, I Gede Yusa:

Penulisan ini membahas tentang Peranan Pegawai Negeri Sipil (PNS) Dalam Penyelenggaraan Pelayanan Terpadu Satu Pintu. Kedudukan dan peranan dari Pegawai Negeri dalam setiap organisasi pemerintah sangatlah menentukan, sebab Pegawai Negeri Sipil merupakan tulang punggung pemerintahan dalam melakukan pembangunan nasional. Permasalahan yang diangkat adalahanalisis mengenai bagaimana PNS dalam menyelenggarakan tugas serta fungsinya dan mengetahui peranannya dalam menyelenggarakan pelayanan terpadu satu pintu. Metode penulisan yang digunakan adalah yuridis normatif, dengan pendekatan konseptual dan peraturan perundangundangan. Kesimpulan dari penulisan ini adalah peranan PNS dalam memberikan pelayanan terpadu satu pintu kepada warga masyarakat merupakan hal penting. Selain itu PNS juga berperan dalam pengelolaan Penyelenggaraan Pelayanan Terpadu Satu Pintu (perizinan) dari tahap permohonan sampai ke tahap penerbitan izin dokumen serta pemberian informasi dalam hal yang akan memperjelas hak dan kewajiban antara pemerintah dengan masyarakat.

14. Evaluasi proses perizinan pelayanan terpadu satu pintu (ptsp) dalam rangka perwujudan good governance (Studi penelitian : UPT PTSP Provinsi Jawa Tengah), Oleh Agnes Anindita Krisilvana:

Dalam era reformasi saat ini sistem pemerintahan yang berbasis good governance mutlak untuk diterapkan, khususnya dalam pelaksanaan pelayanan publik. Pelaksanaan pelayanan publik tidak lagi bertujuan hanya untuk memenuhi undang-undang atau menganggap soal administrasi semata, akan tetapi tentang akuntabilitas pemerintah dan mengedepankan masyarakat. Penerapan good governance selayaknya diterapkan di Pelayanan Terpadu Satu Pintu yang merupakan pelayanan perizinan dimana mulai dari tahap permohonan sampai dengan tahap terbitnya dokumen dilakukan di satu tempat. Tujuan penelitian ini adalah untuk melihat sejauh mana penerapan prinsip-prinsip good governance di Pelayanan Terpadu Satu Pintu Provinsi Jawa Tengah. Selain itu, untuk mengetahui faktor-faktor sukses dan kendala-kendala yang dihadapi dalam pelaksanaan pelayanan perizinan menuju good governance . Penelitian ini menggunakan pendekatan kuantitatif deskriptif dan kualitatif. Data dalam penelitian ini diperoleh dari penyebaran kuesioner, wawancara dengan informan, observasi, dan dokumentasi. Penelitian ini menggunakan pendekatan penelitian studi kasus. Kesimpulan dari penelitian ini menunjukkan bahwa kualitas pelayanan yang terdapat di UPT PTSP Provinsi Jawa Tengah telah mengacu pada prinsipprinsip good governance. Terdapat faktor sukses yang melatar belakangi perwujudan good governance tersebut diantaranya pelaksanaan pelayanan yang berbasis teknologi informasi, tidak adanya pungutan biaya, pegawai PTSP yang berani bertindak tegas menolak kecurangan, dan pengadaan gerai perizinan didaerah luar kota Semarang. Selain itu terdapat juga kendala-kendala yang dihadapi diantaranya penyelesaian perizinan yang tidak tepat waktu, kurangnya ketersediaan pegawai, kerumitan dalam pengajuan perijinan online, dan kurangnya pengamanan atau back up untuk pegawai front office. Saran yang dapat diberikan yaitu lebih diperjelas lagi jangka waktu penyelesaian perizinannya, ditambahnya jumlah pegawai di UPT PTSP, perizinan online yang dibenahi dengan dipermudah dan diperpendek, dan diperkuatnya pengamanan atau back up.

15. A general model of performance and quality for one-stop e-Government service offerings, Oleh Dimitri Gouscos, Manolis Kalikakis, Maria Legal dan Soumi Papadopoulou: 


\section{Implementasi Pelayanan Terpadu Satu Pintu Non-Perizinan Di Ukur Dari Kepuasan Masyarakat Dengan Menggunakan Indeks Kepuasan Masyarakat (Lia Melanie Ginting, Asep Sumaryana, Elisa)}

\begin{abstract}
Makalah ini memperkenalkan kerangka kerja dan metodologi untuk menetapkan indikator dan metrik di memesan untuk menilai kualitas dan kinerja penawaran layanan e-Government satu atap. Sekumpulan dari indikator kualitas dan kinerja dan metrik yang diusulkan telah diturunkan dalam penilaian hasil pendekatan, berdasarkan perspektif penyedia layanan e-Government dan pengguna akhir dan mengikuti garis kerja pertanyaan-metrikmetrik yang berangkat dari beberapa kualitas utama dan manfaat kinerja. Sebuah metodologi yang menggunakan kerangka yang diusulkan untuk menetapkan target peningkatan sesuai dengan alternative skenario disajikan, dan strategi dijabarkan untuk menganalisis akar penyebab kualitas potensial dan kekurangan kinerja dan melakukan tindakan pencegahan yang tepat. Beberapa hasil aplikasi dalam studi kasus nyata, dalam konteks proyek R \& D yang didanai Uni Eropa, juga disediakan. Akhirnya, rekomendasi diberikan tentang kegunaan pendekatan yang diusulkan untuk layanan e-Government penyedia, serta pembuat kebijakan dan keputusan, dan arah pekerjaan di masa depan dibahas secara berurutan untuk meningkatkan cakupan konseptual dari pendekatan ini, sementara pada saat yang sama tidak mengorbankan nya kesederhanaan aplikasi dan keumuman tujuan.
\end{abstract}

Semua penelitian ini meneliti tentang perijinan, hal inilah yang membedakan penelitian yang dilakukan oleh Peneliti, Peneliti meneliti tentang pelayanan terpadu satu pintu yang melayani non-perijinan.

\section{Kesimpulan:}

Berdasarkan Permendagri Nomor 24 Tahun 2006 tentang Penyelenggaraan Pelayanan Terpadu Satu Pintu menjelaskan bahwa kegiatan penyelenggaraan pelayanan terpadu satu pintu bukan hanya tentang perizinan saja melainkan non-perizinan juga dapat diselenggarakan. Pelayanan Terpadu Satu Pintu selalu terkait dengan Kinerja Pegawai Negeri Sipil yang memberikan pelayanan yang memuaskan atau tidak kepada masyarakat.

Kepuasan Masyarakat dapat diukur dengan menggunakan Indeks Kepuasan Masyarakat (IKM) dengan mengacu pada Peraturan Kemenpan R\&B Nomor 25 Tahun 2004 tentang Indeks Kepuasan Masyarakat (IKM). Tujuan mengukur kepuasan masyarakat dengan menggunakan Indeks Kepuasan Masyarakat (IKM) adalah untuk menentukan perkembangan kinerja unit dalam pelayanan instansi pemerintah itu sendiri dan dilaksanakan oleh instansi terkait secara berkala dan dapat digunakan sebagai bahan untuk membuat kebijakan untuk meningkatkan layanan publik.

\section{References}

Achmad Nur Haida, C. S. (2013). Pelayanan Terpadu Satu Pintu Sebagai Upaya Peningkatan Pelayanan Perizinan (Studi Pada Kantor Pelayanan Perizinan Kota Kediri). Jurnal Administrasi Publik, Vol 1, No 2, Publisher: Jurusan Administrasi Publik, Fakultas Ilmu Administrasi, Universitas Brawijaya, 132-138.

Daraba, D. (2015). Analisis Faktor-Faktor Yang Mempengaruhi Kualitas Pelayanan Terpadu Satu Pintu Dalam Rangka Mewujudkan Pemerintahan Yang Baik Di Kabupaten Takalar. Ilmu Administrasi Publik, Vol 5, No.1, Publisher: Program PascaSarjana Universitas Negeri Makassar, 1-8.

Dimitri Gouscos, M. K. (October 2007). A General Model Of Performance And Quality For OneStop e-Government Service Offerings. Government Information Quaterly, Volume 24, Issue 4, Publisher: Elsevier, 860-885.

Ernalita, U. (2014). Efektivitas Organisasi Kantor Pelayanan Perizinan Terpadu Satu Pintu Di Kabupaten Kayong Utara. Jurnal Program Magister Ilmu Sosial Universitas Tanjung Pura, Vol 4, No.0004.

Hastuti, L. A. (November, 2013). Pengaruh Iklim Organisasi Terhadap Kinerja Karyawan Pada Bagian Pelayanan Terpadu Satu Pintu Di Kantor Kota Administrasi Jakarta Pusat. Jurnal Ilmiah Universitas Bakrie, Vol 2, No. 01, Publisher: Universitas Bakrie.

I Putu Agus Indra Febriyana, C. I. (Juli, 2013). Penyelenggaraan Pelayanan Terpadu Satu Pintu. Kertha Negara Vol.01, No.05, Publisher: Kertha Negara.

Krisilvana, A. A. (2017). Evaluasi Proses Perizinan Pelayanan Terpadu Satu Pintu (PTSP) Dalam Rangka Perwujudan Good Governance (Studi Penelitian: UPT PTSP Provinsi Jawa Timur). Journal Of Politic and Government Studies, Vol 6, No 01, Publisher: Journal Of Politic and Government Studies, 11-20.

Meray, I. M. (2014). Implementasi One Stop Service (OSS) Pada Badan Pelayanan Perizinan Terpadu (BP2T) Kota Manado. Jurnal Administrasi Publik, Vol 1, No.1, Publisher: Sam Ratulangi University. 
Mitha Ananda Putri, P. A., \& Yusa, I. G. (Juni, 2016). Peranan Pegawai Negeri Sipil Dalam Penyelenggaraan Pelayanan Terpadu Satu Pintu. Kertha Negara Vol. 04, No.04, Publisher: Kertha Negara.

Nopiyanti, W. H. (2015). Analisis Indeks Kepuasan Masyarakat Pada Pelayanan Perijinan Di Badan Penanaman Modal Dan Pelayanan Perizinan Terpadu Satu Pintu (BPMPPTSP) Kabupaten Semarang. Journal Of Public Policy and Management Riview Vol 4, No 3, Publisher: Jurusan Administrasi Publik, Fakultas Ilmu Sosial dan Ilmu Politik, Universitas Diponegoro, 1-11.

Priyani Dini Pramita, S. R. (2014). The Implementation Of Integrated One-Stop Service at Licensing Service To Society (Case Study On Business License Service At Investment And Integrated Licensing Service Agency (IILSA) Of Pasuruan City). WACANA, Jurnal Sosial dan Humaniora, Vol 17, No 3, 149-158.

Putri Widayanti, P. A. (2014). Studi Evaluasi Proses Pelayanan Prima Perijinan Terpadu Satu Pintu Di BPPT Kota Semarang. Journal Of Politic and Government Studies, Volume 3, Nomor 2, 176-185.

Setiawan, B. (2014). Pengaruh Kompetensi Dan Motivasi Terhadap Kinerja Pegawai Negeri Sipil Di Lingkungan Badan Penanaman Modal Dan Pelayanan Terpadu Satu Pintu (BPMPTSP) Provinsi Kalimantan Barat. Jurnal Manajemen dan Bisnis, Vol.1, No. 1.

Sri Hartati, N. H. (2013). Kinerja Organisasi Pelayanan Publik Pada Kantor Pelayanan Terpadu Satu Pintu Kabupaten Sintang. Jurnal Program Magister Ilmu Sosial Universitas Tanjung Pura, Vol 1, No.0001; ILMU ADMINISTRASI NEGARA.

Yuli Tirtariandi El Anshori, E. A. (2014). Implementasi Pelayanan Perizinan Terpadu Satu Pintu. JIANA (Jurnal Ilmu Administrasi Negara), Vol. 12, No.4. 